\section{THE QURANIC CONCEPT OF PEACE AND HUMANITY ${ }^{1}$}

\section{Patchrathanyarasm Salamat}

\begin{abstract}
The Quran is the principal source of reference in Islam. Some people outside the Muslim world relate the religion to violence and value Islam according to what some of its fellows, the Muslims, have done in the name of Islam. The principle of judgement thus has unfortunately drifted away from its true source and meaning. The very basic concept of peace and humanity as stated in the Quran seems to have no place in reality at all. This paper will bring such issues back to our attention and show the true teachings of this most distorted of religions.
\end{abstract}

\section{Introduction}

Along with its fast growing number of believers, the distorted values of Islam are fast spreading among non-Muslims via various channels. Having used Arabic as medium for revelation up to the last Prophet who was born an Arab and propagated his mission among the Arabs, Islam has since then been equated with

\footnotetext{
${ }^{1}$ This article is part of the author's doctoral dissertation on "Islam, Media, Violence: A Journey through Media's Construction of Islam's Violent Image", Doctor of Philosophy Program in Integrated Science, College of Interdisciplinary Studies, Thammasat University, Bangkok, Thailand. The author is grateful to Thailand Research Fund for granting her a Golden Jubilee award, which fully supported her doctoral study.
}

Arabs and seen as the Arabs' religion. In fact, fewer than one fifth of the Muslims in the world are Arabs. ${ }^{2}$ Moreover, without having understood the true values of Islam, which are prescribed in Arabic, some have even further equated (the practices of) Muslims with Islam. Not being aware of the different meanings of terms has thus made the word "Islamic" frequently misused.

As with all other religions that teach peace and harmony, the philosophy and principle teachings of Islam are truly based on peace and humanity, not violence. In an attempt to illuminate the true teachings, this paper will first clarify the meaning of two main words, Islam and Muslim. A brief description of the Quran and the Traditions of the Prophet will then follow before the Quranic concept of peace and humanity, the implementation as illustrated by the Prophet, and the true meaning of jihad are given.

\section{The meanings of Islam and Muslim}

Most people outside the Muslim world seem to equate "Islam" with "Muslim." These two words, however, though related are not identical.

"Islam" is a word that does not have any connection with a geographical area or a particular figure or character in history. To Muslims, "Islam" is not just a "religion" as in the common meaning that conveys only religious beliefs, doctrines and rituals, but it is the whole encompassing

\footnotetext{
${ }^{2}$ See more detail concerning this statement in the author's doctoral dissertation (Salamat 2005).
} 
way of life. Al Qur'an (The Quran), ${ }^{3}$ the principal source of reference for all Muslims, has used the word din or deen which, even though usually translated as "religion," denotes various meanings in different contexts in prescribing this set of beliefs and moral code of life. The most important and common are that guidance (2: 16); way or system of life $(3: 19,10$ : 104-109, 48: 28); path, way, law, constitution $(5: 3,12: 76)$; penal law (24: 2); faith (3: 83); the collection of moral, spiritual and worldly principles, system, way of conduct $(33: 5,40: 26)$; peace and order (8: 39); servant-hood, obedience (7: 29, 10: 22, 16: 52, 29: 65, 31: 31, 39:2); and judgement, reward, punishment (1: 4 , 51: 6, 82: 18-19, 37: 53, 56: 86).

Islam thus further has, besides its general and social view as a religion or a set of beliefs and a social order, at least three relevant core meanings. In semantic array, Islam, which is a verbal noun derived from the Arabic root "سلم (s-1-m)" of the primary verb salama or aslama, means peace and peaceful way, submission, surrender, salvation, devotion, obedience and purity. In the theological sense, Islam means full submission to the Will of the

\footnotetext{
${ }^{3}$ Al Qur'an is in Arabic only. All other languages besides Arabic can only be considered as a translation of the meaning of the Quran, not the Quran itself. Every translation is an interpretation. Translation of the meaning that is contained in the Quran is solely the effort of the translator. It is not divine, nor inspired. All one has access to are numerous books that explain its meaning and implications, and the choice of words made by translators. As such, some translations, especially those of non-Muslims, are in conflict with each other and contain numerous errors when compared to the original Quran and the explanation made by traditional devout Muslims scholars.
}

One God (and in compliance with the obedience to His Guidance). In political terms, Islam means the constitution that governs every aspect of human beings. Anything that employs the word "Islam," be it "Islamic" or "Islamism," or has claimed to do so in the name of "Islam" must fall within such criteria meanings.

The original meaning of "Islam" in the language of the Quran is the way of those who wholeheartedly submit and the readiness of a person to accept and follow God's command. Whereas "Muslim" is also a word that is taken from the same root salama as Islam, but it applies, in the first place, to a person who is ready to take and follow God's commandment:

And who could be of better faith than he who surrenders his whole being unto God and is a doer of good withal, and follows the creed of Ibrahim (Abraham), who turned away from all that is false - seeing that God exalted Ibrahim with His love? (Quran 4: 125);

Ibrahim was neither a "Jew" nor a "Christian," but was one who turned away from all that is false, having surrendered himself unto God; and he was not of those who ascribe divinity to aught beside Him. (Quran 3: 67);

His Lord said to him, 'Devote yourself to Me.' Ibrahim replied, 'I devote myself to the Lord of the Universe,' and commanded his sons to do the same, as did Yaqub (Jacob): 'O my sons, surely God has chosen for you (this) faith, therefore make sure you devote yourself to Him, to your dying moment. (Quran 2: 131-132) 
According to the Quran, the word Muslim clearly points to persons who seek full surrender to God by adhering to a righteous path. Thus, being a Muslim generally means one who fully submits to the Will of God. The way in which a Muslim shows submission to the One God is through the conduct in which his or her deeds aim to comply by God, with God and for God.

After the advent of the last Messenger of the One God, however, the word "Muslim" acquired the specific meaning referring to a person who follows the message announced by Muhammad and believes in its truthfulness. The more specific meaning of the word is closely related to the original one because Muhammad stated that his teachings contain the teachings of all previous God's messengers and prophets ${ }^{4}$ : starting from Adam to Nuh (Noah), Ibrahim (Abraham), Ishaaq (Isaac), Ismail (Ishmael), Yaqub (Jacob), Musa (Moses), Dawud (David), Sulaiman (Solomon), Isaa (Jesus), and all the divine commandments. When a person professes a belief in the truthfulness of Muhammad and pledges to follow the message he announced, he or she is, in fact, stating his or her readiness to obey the commands of God unconditionally.

Meanwhile, when a person states that he or she believes in the truthfulness of Muhammad, he or she actually states his or her belief in all that Muhammad announced, the Quran, and in all his practices of implementation: all the deeds

\footnotetext{
${ }^{4}$ There were about 124,000 prophets in total (Musnad Ibn Hanbal, Hadeeth 21257). While a messenger is a prophet who has additionally been given message to revive or establish a new social order, all messengers are prophets but not all prophets are messengers.
}

and all the sayings of Muhammad whether in matters of belief or in areas of practice.

Hence, even though "Islam" and "Muslim" are correlated, they are not the same and interchangeable. While "Islam" stands for the path or way of life that is prescribed, "Muslim" is for people who willingly submit or, at least, vow and claim to submit themselves to follow the path and the Will of God. Nevertheless, as happens in all other religions or belief systems, not all believers are righteous and true fellows. As people differ, so Muslims differ. Since Muslims differ, the "Islam of Muslims" according to their understanding and interpretation may also be so various and this has transformed "practical Islam of practising Muslims" into sects and schools. However, as long as their interpretation and implementation are truly based on the Quran, which in many verses invites people to reason and critically analyze its teachings, and the Traditions of Implementing of the last Messenger of God, they all bound to and in the realm of "Islam." As such, things, actions or concepts that have no grounds in the Quran nor in the authentic Traditions of the Prophet cannot be claimed to be "Islamic."

\section{The Quran as the first source of reference}

The Quran, which is derived from the Arabic root qara'a meaning "recitation," is the sacred text of Islam and the highest authority in all matters.

To Muslims, the Quran is truly the literal Word of God that was revealed to His last Messenger, the Prophet Muhammad, on various occasions to answer questions, solve problems, to settle disputes and to be the human's best guide to the truth. The 
Quran was recited, memorized and written down on various available materials throughout Muhammad's twenty-three prophetic years. In fact, Muslims are the only ones to even claim to have an authentic scripture from God, in its original form, in which not a single letter has been changed.

Muslims believe the Quran to be a flawless record of the revelations that Archangel Gibreel (Gabriel) delivered to the Prophet Muhammad from 610 CE until his death in $632 \mathrm{CE}$.

The name "Quran" came from Gibreel's initial command to Muhammad, the illiterate, to "Recite!" Recitation is thus considered a fundamental concept associated with the Quran. The first followers of the Prophet memorized his recitation in order to recite it to others, following an established Arabic grammatical method for preserving poetry.

Although the verses of the Quran were memorized and written down on various forms of material during the Prophet's lifetime, they started to be collected and bound in book format to preserve the content from corruption only shortly after his death. In around December $632 \mathrm{CE}$, a few months following the Prophet's death, written collections started to take form in the caliphate of Abu Bakr. Later in 653/654 CE, the caliph Uthman standardized one particular text. The text was then further given vowel pointing and punctuation in the seventh and eighth century.
The Quran totally consists of 6346 ayat $^{5}$ (verses) in 114 surahs (chapters) ${ }^{6}$ of 30 $y u z$ (sections) which widely vary in length. With the exception of the opening chapter (Al-Fatihah), all the other chapters are generally arranged from the longest to the shortest. As a result, they are not in chronological order. ${ }^{7}$

Since the ayat or verses have two main categories: obvious and hidden (Quran 31: 20 ), the need to have grounds of explanation after the life of the Prophet and the Companions' period, somehow, led to laying down a science of interpreting the Quran or the rules of tafseer (exegesis). ${ }^{8}$ Even though there are both Muslims and non-Muslims who have written commentaries on the Quran, the majority of Muslim scholars insist that the mufassir (exegete or commentator) must

\footnotetext{
${ }^{5}$ This word literally means sign or proof and Muslims regard each ayah (singular form) as a sign from God. It usually refers to a unit or passage, both numbered and un-numbered, in the Quran, and is normally translated as "verse."

${ }^{6}$ There are 6234 numbered verses and 112 un-numbered verses of Basmalahs, which explicitly appeared as the first verse of 112 chapters though is conspicuously absent from chapter 9 and appears twice in chapter 27 .

${ }^{7}$ This order of verses and chapters was done by the Prophet himself with some supervision of the Archangel Gibreel who came to recite and review with him every month of Ramadan (month of fasting which is the $9^{\text {th }}$ month of Islamic Lunar Calendar) throughout twentythree years with special notice to his last Ramadan when the recitation was done twice. ${ }^{8}$ There are three basic groups of exegesis: by transmission, by sound opinion or knowledge, and by indication (from signs) (von Denffer 1994). Besides group classification, deeper rules had been set on classification of words and verses as well (World Islamic Network: $<$ http://www.muslims.ws/win/quran/tafseer/Il m-ul-usul.htm $>$ ).
} 
be a Muslim, since the exegete should be one who is sound in belief; well-grounded in the knowledge of Arabic and its rules as a language; "have the ability for precise comprehension" of the Quran and "abstain from the use of mere opinion" (von Denffer 1994: 122). A mufassir should possess the knowledge of the science of reciting the Quran; should know the science of interpreting ahadeeth well enough to recognize that which is ambiguous, and to elaborate on that which is brief or abridged; and must have studied thoroughly the various schools of thought. Having also knowledge of the reasons for the revelation of the different verses and knowledge about the theory of the abrogation of verses of the Quran is another qualification (Doi 1984: 35).

Regardless of what is laid down, the first and highest source of tafsir or interpretation of the Quran is by the Quran whilst the second source is via the Traditions of the Prophet.

Naturally, the explanation of the Qur'an by the Qur'an and the explanation of the Qur'an by the Prophet are the two highest sources for tafsir...

The interpretation of the Qur'an by the Qur'an is the highest source of tafsir. Many of the questions, which may arise out of certain passage of the Qur'an, have their explanation in other parts of the very same book, and often there is no need to turn to any sources other than the word of Allah, which in itself contains tafsir. To seek to explain an aya from the Qur'an by referring to another aya from the Qur'an is the first and foremost duty of the mufassir (exegete). Only if this does not suffice, will he refer to other sources of tafsir.

(von Denffer 1994: 124)

Normally the interpretation of the verses of the Quran is not only made with reference to the grammatical and thematic aspects of the verses but to historical context as well. While some of the verses were revealed addressing issues current to that time of history, others were revealed addressing general principles or matters applicable to every time and place. Even though all the verses serve as guidance for Muslims, the substance addressed to a specific location with specific people may or may not apply to subjects outside the scope of the verses. Unless the addressees are elucidated, the Quranic verses will not be interpreted correctly. All of the Quranic "statements and ordinances are mutually complementary and cannot, therefore, be correctly understood unless they are considered as parts of one integral whole" (Asad 1980: 261).

Misinterpretation of the verses of the Quran occurs when the historical, grammatical and thematic contextual aspects are not taken into consideration. Unfortunately, while some non-Muslims wrongly accuse Islam of teaching violence, some Muslims also abuse its teaching based on an improper understanding of a few "selectively and partially" picked of verses of the Quran that were actually addressed to a specific group of people and have a specific historical background.

Nevertheless, apart from the above principles of interpretation, God has already mentioned in His literally guiding path, the Quran, that it is His subjects' duty to warily interpret and implement. For that, in all matters, the interpretation 
and implementation must rebound to the word "Islam" which has the literally clear purpose of having named His path as such if one will deeply consider it with a clear mind of devout believing.

Will they not, then, try to understand this Quran? Had it issued from any but God, they would surely have found in it many an inner contradiction! (Quran 4: 82)

...Indeed, We have made all the signs manifest unto people who are endowed with inner certainty. (Quran 2: 118)

...We have indeed made the signs [thereof] clear unto you, if you would but use your reason. (Quran 3: 118)

...And never did We send those signs for any other purpose than to convey a warning. (Quran 17: 59)

\section{The traditions as the second source of reference}

"Traditions" is a translation of the Arabic word Sunnah which denotes the way the Prophet Muhammad lived his life. The Sunnah is the second source of reference after the Quran. Both sources, however, are indispensable since one cannot practice "Islam" without consulting both of them. As mentioned in the Quran (59: 7), this means ". . . Hence, accept [willingly] whatever the Apostle gives you [thereof], and refrain from [demanding] anything that he withholds from you; and remain conscious of God: for, verily, God is severe in retribution."
While the Arabic word hadeeth (pl. ahadeeth) is very similar to sunnah, they are not identical. A hadeeth is a narration or report of the life of the Prophet or what was transmitted on the authority of the Prophet, his deeds, sayings or tacit approval of other people's actions. Thus, it is not identical to the Sunnah, which is his life (sayings and practices) itself. According to Azami (1977), hadeeth literature not only consists of the narrations of the life of the Prophet and the things that he approved but the term was sometimes used in a broader sense to cover narrations about the Companions (of the Prophet) and their successors (to the Companions) as well.

As a result, when referring to the Traditions of the Prophet, even though the best source of reference for his life is still the Quran, yet one needs to base it also on ahadeeth, which, as with the Quran, requires a science of collecting and interpreting.

Although the Prophet commanded his Companions not to write down his sayings and practices of implementing God's commands during the early period of "Islam," in which the wisdom behind this was not to mix the hadeeth with the Word of God, his Traditions were systematically collected and written down in about the second century of Islam (Sieny 2000).

The science of collecting, analyzing, compiling, grading and reporting ahadeeth became a special field of studies after the Companions' period. The leading compiled reports are from Al-Bukhari, Muslim, At-Tirmidhi, Abu Dawud, AnNasai and Ibn Majah, which are widely known as the six most authentic books. The validity of a hadeeth depends solely on its agreement with the Quran, while the 
grading of a hadeeth depends on the reliability of the chain of narrators who reported it. In order to approve the reliability of the chain, the compiler must first study the characters and life of every single person who has been mentioned in the chain of narrators. The utmost care must be given not only in reporting the exact words, but also in sifting through the characters of the people who reported them. If any single person in the chain of narrators was reported to be of doubtful character or unreliable, either the entire hadeeth would then have been rejected or this fact would have to be noted down and specifically mentioned.

\section{Quranic concept of peace and humanity}

In Islam, human beings have been endowed with an especially high ranking status in the hierarchy of all the known creatures of God (Quran 17: 70). One can occupy this distinguished position because one has been gifted with rational faculties and spiritual aspirations as well as the power of action. Since human beings possess the qualities of intelligence and choice, they are thus invited to submit to the Will of God and to obey His Commandments respectively. Submission to the Will of God, together with obedience to His beneficial Law, is the best safeguard for humanity's peace and harmony.

\section{Concept of the universal outlook and humanity}

Muslims believe that God created the universe and everything in all galaxies so that He could be known and recognized in all His Names and Attributes. ${ }^{9}$ God's creation includes one creature with free will, humanity. Of all creatures, only humans can manifest the Divine Names of the All-Willing, All-Knowing, and AllSpeaking since God has endowed human beings with free will, the knowledge (names) of things (Quran 2: 31), and made them His trustee or vicegerent to rule on earth according to His laws (Quran 2: 30, 6: 165, 7: 129, 142). Having free will means that one must choose and each person's life then consists of choosing between what is right and what is wrong because God has created in human the mind; the ability to understand; the soul and conscience to be good and righteous; and the feelings and sentiments to be kind and humane to all other creatures in the universe.

\section{The viewpoints on the universe and nature}

As Muslims believe in pure monotheism and reject the views of those who give the human characteristics of weakness and imperfection to the Divine, this world is thus believed not to have created itself nor to have come from nothing. It is a product of Intelligence rather than chance.

In Islam, God is the absolute Creator and the true Owner of sovereignty. The sovereignty of God extends to the entire universe, the whole of humanity and all organizations. God is the real source of religion, philosophy and law, and the bestower of power, strength and authority.

\footnotetext{
${ }^{9}$ God has 99 beautiful names in which $\mathrm{He}$ apparently manifests His attributes or divine qualities. When dividing the names into positive and negative attributes, only four or five fall in the latter category (Ahmed 2002: 29).
} 
To God belongs the dominion over the heavens and the earth, and God has the power to will anything. (Quran 3: 189);

His is the dominion over the heavens and the earth; He grants life and deals death; and $\mathrm{He}$ has the power to will anything. (Quran 57: 2);

Say, O God! Lord of all dominion! Thou grantest dominion unto whom Thou willest and takest away dominion from whom Thou willest; and Thou exaltest whom Thou willest and abasest whom Thou willest. In Thy hand is all good. Verily, Thou hast the power to will anything. (Quran 3: 26)

God is distinct from His creation and there is nothing like unto Him. We humans cannot describe or attain the utmost of His greatness, which is as $\mathrm{He}$ describes Himself in the Quran:

Allah (God). There is no god but He, the Living, the SelfSubsisting, the Eternal. No slumber can seize Him nor sleep. His are all things in the heavens and on earth. Who there can intercede in His presence except as He permits? His Throne extends over the heavens and the earth and $\mathrm{He}$ feels no fatigue in guarding and preserving them for $\mathrm{He}$ is the Most High, the Supreme in glory. (Quran 2: 255);

He is God the Creator, the Maker, the Fashioner; His are the most excellent names; whatever is in the heavens and the earth declares
His glory; and He is the Mighty, the Wise. (Quran 59: 24);

Say, He is God the One. The SelfSufficient Master, Whom all creatures need, He neither eats nor drinks. He fathered no one nor was $\mathrm{He}$ fathered. And there is none co-equal or comparable unto Him (Quran 112: 1-4).

As such, there is an inseparable relationship between God, nature and humanity. Nature and humanity are two "books" written with different material but having the same meaning.

The Quran in many verses deals with the objects and events of the universe as signs of nature. These verses project the universe as a model of peace and harmony. There are innumerable astronomical bodies in space. All are in motion but all follow their own orbits without the slightest deviation. Holding up this phenomenon as a model, the Quran asks humanity to follow the same course of peace, that is, to move in one's own orbit and not trespass.

Do they seek, perchance, a faith other than in God, although it is unto Him that whatever is in the heavens and on earth surrenders itself, willingly or unwillingly, since unto Him all must return?

(Quran 3: 83)

"Islam", submission to the Will of God, hence is also considered as the universal order, the integral way of harmony, and the unique system that harmonizes the physical with the metaphysical, the rational with the ideal, and the corporeal with the spiritual. Peaceful living is thus taken as the way for both humanity and 
the universe. Through a progressive deepening and widening of their insight into the wonders of the universe as well as through a deeper understanding of one's own psyche-all of which points to the existence of a conscious Creator, should be enough to remind humans of their responsibility before Him.

We will soon show them Our messages [through what they perceive] in the utmost horizons [of the universe] and within themselves, so that it will become clear unto them that this [revelation] is indeed the truth. [Still,] is it not sufficient [for them to know] that thy Sustainer is witness unto everything?

(Quran 41: 53)

Humanity then is a Divine Book that corresponds to the Quran and the universe, and human life is so interrelated with natural phenomena that even the laws of history can be deduced from the laws of nature:

Verily, your Sustainer is God, who has created the heavens and the earth in six aeons and is established on the throne of His almightiness. He covers the day with the night in swift pursuit, with the sun and the moon and the stars subservient to His command: oh, verily, His is all creation and all command. Hallowed is God, the Sustainer of all the worlds! Call unto your Sustainer, humbly and in the secrecy of your hearts. Verily, He loves not those who transgress the bounds of what is right: hence, do not spread corruption on earth after it has been so well ordered. And call unto Him with fear and longing: verily, God's grace is ever near unto the doers of good! And He it is who sends forth the winds as the glad tidings of His coming graceso that, when they have brought heavy clouds, We may drive them towards dead land and cause thereby water to descend; and by this means do We cause all manner of fruit to come forth. Even thus shall we cause the dead to come forth: [and this] you ought to keep in mind. As for the good land, its vegetation comes forth [in abundance] by its Sustainer's leave, whereas from the bad it comes forth but poorly. Thus do We give many facets to Our messages for [the benefit of] people who are grateful!

(Quran 7: 54-58)

The above verses apparently discuss natural phenomena yet mention the Resurrection and importance of prayer. They indicate that God commands everything and $\mathrm{He}$ has no partners in either creation or command. Corruption in the land is forbidden. The main principles of faith (belief in God's Oneness and the Resurrection) are emphasized as well as to remind us that, as God's vicegerents, we are to pray, establish justice and avoid corrupting and transgressing the Divine law.

Moreover, these verses console believers living as small-oppressed minorities amidst a corrupt, wrongdoing community with the good tidings that victory is near as long as they keep striving for God's cause and seeking help in patience and prayer. 
Thus, revelation is inseparable from the cosmic revelation, which is also a book of God. By refusing to separate humanity from nature, Islam preserves an integral view of the universe and sees the flow of Divine grace in the arteries of the cosmic and natural order. As one seeks to transcend nature from its very bosom, nature can be an aid to this process, provided that one learns to contemplate it as a mirror reflecting a higher reality:

Verily, in the creation of the heavens and the earth and in the succession of night and day, there are indeed messages for all who are endowed with insight, [and] who remember God when they stand and when they sit and when they lie down to sleep and [thus] reflect on the creation of the heavens and the earth: "O our Sustainer! Thou hast not created [aught of] this without meaning and purpose. Limitless art Thou in Thy glory! Keep us safe, then, from suffering through fire!"

(Quran 3: 190-91)

In fact, humanity is the channel of grace for nature, for our active participation in the spiritual world causes light to enter the world of nature. Due to our intimate connection with nature, our inner state is reflected in the external order. Thus, when our inner being turns to darkness and chaos, nature turns from harmony and beauty to disequilibrium and disorder. We see ourselves reflected in nature and penetrate into nature's inner meaning by delving into our own inner depths. Those who live on the surface of their being can study nature as something to be manipulated and dominated, while those who turn toward the inner dimension of their existence can recognize nature as a symbol and come to understand it in the real sense.

This concept of humanity and nature, as well as the presence of a metaphysical doctrine and a hierarchy of knowledge, enabled Muslim communities to develop many sciences that were influential in the West's own development of science and yet did not disturb their Islamic intellectual edifice. An elaborate hierarchy of knowledge integrated by the principle of tawhid (Divine Unity) in Islam includes astronomical, juridical, social and theological sciences such as the spiritual and the metaphysical. All of these derive their principles from the Quran. Muslim scholars have no tradition of separating the study of nature from knowing God. Muslim scientists, such as Jabir ibn Haiyan, Al Khwarizmi, Al Farghani, Al jahiz, A Kindi, Al-Tabari, Ibn Sina (Avicenna), Nasir al-Din al-Tusi and many more have always considered observing and contemplating nature as very important aspects of their spiritual journey.

As such, every creature is intoxicated, according to its capacity, within the spheres of the universal manifestations of God's Names and Attributes. Their obedience to God's laws for the universe's creation and operation, which comprise their worship, glorification and specific praise and exaltation of Him, as well as the attainment of Divine purposes for their lives, please Him to a degree beyond our comprehension.

For all the great favors and mercy, God does not need anything in return because $\mathrm{He}$ is Needless and Independent. God asks human beings to know Him, to love Him and to enforce His commandments for humanity's own benefit and good sake. 
Worshipping God does not mean that one has to spend an entire life in constant seclusion and absolute meditation. To worship God is to know Him, to love Him, to live one's life according to His commandments, to enforce His guidance in every aspect of life, to serve His cause by doing right and shunning evil and to be just to Him, to ourselves, to our fellow human beings and to all other creatures in the universe.

\section{Human beings as God's creatures and trustees}

Humanity is located at the axis and center of the cosmic milieu. By being taught the names of all things, Adam, the first human being, received the keys to a knowledge of things and so gained domination over them. The power a human receives, however, is only in one capacity of serving God as His khalifa (trustee, inheritor, successor or vicegerent) on earth, not as one who rebels against Him and His Will nor His other creatures.

For, He it is who has made you inherit the earth and has raised some of you by degrees above others, so that He might try you by means of what He has bestowed upon you. Verily, thy Sustainer is swift in retribution: yet, behold, $\mathrm{He}$ is indeed much-forgiving, a dispenser of grace. (Quran 6:165)

$\mathrm{He}$ it is who has created for you all that is on earth and has applied His design to the heavens and fashioned them into seven heavens; and $\mathrm{He}$, alone, has full knowledge of everything. And Lo! Thy Sustainer said unto the angels, "Behold, I am about to establish upon earth one who shall inherit it." They said, "Wilt Thou place on it such as will spread corruption thereon and shed blood - whereas it is we who extol Thy limitless glory, and praise Thee, and hallow Thy name?" [God] answered: "Verily, I know that which you do not know." And $\mathrm{He}$ imparted unto Adam the names of all things; then $\mathrm{He}$ brought them within the ken of the angels and said: "Declare unto Me the names of these [things], if what you say is true." (Quran 2: 29-31)

O humankind! Worship your Sustainer, who has created you and those who lived before you, so that you might remain conscious of Him who has made the earth a resting-place for you and the sky a canopy, and has sent down water from the sky and thereby brought forth fruits for your sustenance: do not, then, claim that there is any power that can rival God, when you know [that He is One]. (Quran 2: 21-22)

Meanwhile, since God's existence, not to mention His mercy, does not depend on human perception and realization, so God's path does not necessarily mean to be employed by every single human being or group. They are only two main groups of His subjects before Him: the believers who have faith in Him and non-believers who have no faith in Him. Among these two main groups, what has further distinguished one from the other is virtue. For everyone before God is equal except in one's deeds. As such, the Quran has further described the true servants of God as: 
For, [true] servants of the Most Gracious are [only] they who walk gently on earth, and who, whenever the foolish address them, reply with [words of] peace; and who remember their Sustainer far into the night, prostrating themselves and standing; and who pray: "O our Sustainer, avert from us the suffering of hell - for, verily, the suffering caused by it is bound to be a torment dire: verily, how evil an abode and a station!"; and who, whenever they spend on others, are neither wasteful nor niggardly but [remember that] there is always a just mean between those [two extremes]; and who never invoke any [imaginary] deity side by side with God, and do not take any human being's life - [the life] which God has willed to be sacred - otherwise than in [the pursuit of] justice, and do not commit adultery. And [know that] he who commits aught thereof shall [not only] meet with a full requital [but] shall have his suffering doubled on Resurrection Day: for on that [Day] he shall abide in ignominy. Excepted, however, shall be they who repent and attain to faith and do righteous deeds: for it is they whose [erstwhile] bad deeds God will transform into good ones-seeing that God is indeed much forgiving, a dispenser of grace, and seeing that he who repents and [thenceforth] does what is right has truly turned unto God by [this very act of] repentance. And [know that true servants of God are only] those who never bear witness to what is false, and [who], whenever they pass by [people engaged in] frivolity, pass on with dignity; and who, whenever they are reminded of their Sustainer's messages, do not throw themselves upon them [as if] deaf and blind; and who pray "O our Sustainer! Grant that our spouses and our offspring be a joy to our eyes, and cause us to be foremost among those who are conscious of Thee!" [Such as] these will be rewarded for all their patient endurance [in life] with a high station [in paradise], and will be met therein with a greeting of welcome and peace, therein to abide: [and] how goodly an abode and [how high] a station!

(Quran 25: 63-76)

Being God's trustee or vicegerent makes every "Muslim" a "priest." Everyone has direct access to God. If one would like God to talk, simply read the Quran. Likewise, when one would like to talk to God, pray to Him.

\section{The mercy of God upon humanity}

We have honored the children of Adam; provided them with transport on land and sea; given them for sustenance things good and pure; and conferred on them special favors above a great part of Our creation.

(Quran 17: 70)

Muslims believe that the Mercy of God has endowed humanity from the very beginning of human history and that Muhammad and all other messengers and prophets throughout the existence of human beings, including Adam, Nuh (Noah), Ibrahim (Abraham), Musa (Moses) and Isaa (Jesus) were all sent 
from God. They were all called to the same path, submission to the Creator, alone with no partner. It has been the mission of every messenger to establish an ethical ideal and a system of life, having its basis in the sovereignty of God. The Muslim millat $^{10}$ (path/way) is obliged with the duty of raising humanity to a higher, nobler spiritual state of life and to the duty of perfecting the world order (Iqbal in Ahmad 1991: 232-233).

[Does man ever consider] out of what substance [God] creates him? Out of a drop of sperm He creates him, and thereupon determines his nature, and then makes it easy for him to go through life; and in the end $\mathrm{He}$ causes him to die and brings him to the grave; and then, if it be His Will, He shall raise him again to life, Nay, but [man] has never yet fulfilled what He has enjoined upon him!

(Quran 80: 18-23)

Not one of all [the beings] that are in the heavens or on earth appears before the Most Gracious other than as a servant - indeed, He has full cognizance of them, and has numbered them with [unfailing] numbering; and every one of them will appear before Him on Resurrection Day in a lonely state. Verily, those who attain to faith and do righteous deeds will the Most Gracious endow with love: and only to this end have We made this [divine writ] easy to understand, in your own tongue, [O Prophet,] so that you might convey thereby glad tidings to the

\footnotetext{
${ }^{10}$ This word usually means a way or path but can also refer to a faith and belief system.
}

God-conscious and warn thereby those who are given to [futile] contention: for, how many a generation have We destroyed before their time -[and] can you perceive any one of them [now], or hear any whisper of them?

(Quran 19: 93-98)

And [thus, O Prophet,] We have sent thee as [an evidence of Our] grace towards all the worlds.

(Quran 21: 107)

Now [as for thee, O Muhammad,] We have not sent thee otherwise than to humankind at large, to be a herald of glad tidings and a warner; but most people do not understand [this], (Quran 34: 28)

It is He (God) Who has sent among the illiterates a Messenger from among themselves to recite His revelations to them, to make them grow spiritually, and teach them the Scripture and wisdom before they were clearly astray to them and others yet to join them. (Quran 62: 2-3)

Alif Lam Ra. A Divine writ [is this -a revelation] which We have bestowed upon thee from on high in order that thou might bring forth all humankind, by their Sustainer's leave, out of the depths of darkness into the light: on to the way that leads to the Almighty, the One to whom all praise is due. (Quran 14: 1)

And never have We sent forth any apostle otherwise than [with a message] in his own people's tongue, so that he might make [the 
truth] clear unto them; but God lets go astray him that wills [to go astray], and guides him that wills [to be guided] - for He alone is almighty, truly wise. (Quran 14: 4)

Besides His guidance, God has endowed humanity with the principal faculties fundamental to our survival and in carrying out our function as His viceregents: an appetite for such things as the opposite sex, offspring, livelihood and possessions; power or forcefulness in defence and struggle; and reason or intellect. Since human beings are tested in this worldly life and are free to choose, God does not restrict these faculties. So, one who works out his or her salvation through the guidance of God does it for one's own benefit. No one can act on behalf of another or intercede between him and God, except by His permission (Quran 2: 255, 21: 28). In order to obtain salvation, a person must combine faith and action, belief and practice. Faith without doing good deeds is as insufficient as doing good deeds without faith. A Muslim believes that God does not hold any person responsible until He has shown him or her the Right Way. A human being must build his or her faith on well-grounded convictions beyond any reasonable doubt and above uncertainty.

Verily, for all men and women who have surrendered themselves unto God, and all believing men and believing women, and all truly devout men and truly devout women, and all men and women who are true to their word, and all men and women who are patient in adversity, and all men and women who humble themselves [before God], and all men and women who give in charity, and all self-denying (fasting) men and self-denying (fasting) women, and all men and women who are mindful of their chastity, and all men and women who remember God unceasingly: for [all of] them has God readied forgiveness of sins and a mighty reward.

(Quran 33: 35)

Moreover, differences in race, tribe, nation and family have no legal authenticity and they are not the basis of unity or criteria of superiority and inferiority. They are only the means of facilitating human relations:

O humanity! Surely, We have created you of a male and a female and made you tribes and families that you may know each other; surely, the most honorable of you with God is the one among you most careful of his duty.

(Quran 49: 13)

And had thy Sustainer so willed, He could surely have made all humankind one single community: but $[\mathrm{He}$ willed it otherwise, and so] they continue to hold divergent views [all of them,] save those upon whom thy Sustainer has bestowed His grace. But [as for those who refuse to avail themselves of divine guidance,] that word of thy Sustainer shall be fulfilled: "Most certainly will I fill hell with invisible beings as well as with humans, all together!"

(Quran 11: 118-119)

Thus, the purpose of divisions into tribes and groups is for knowing one another better, not for taking pride, showing love or hate, seeking superiority or engaging in disputes. The only criteria are faith, belief 
and chastity. The Prophet has repeatedly declared that human beings form a single $u m m a h^{11}$ and there is no authenticity in territorial or racial superiority. Color of skin is no criteria of superiority or inferiority. The only criteria are faith, conduct and proper behavior. No blood relationship can be the means of pride or superiority.

God, Most High, has removed from you the pride of the preIslamic period and its boasting in ancestors. One is only a pious believer or a miserable sinner. You are sons of Adam, and Adam came from dust. Let the people cease to boast about their ancestors. They are merely fuel in Jahannam (Hell); or they will certainly be of less account with God than the beetle which rolls dung with its nose."

(Abu Dawud, Hadeeth 5097)

In Islam, human life will surely be directed to a certain purpose, that is, to be her or himself a tool in the hand of the higher Supreme. That is the Straightway and to achieve that goal requires "knowledge". Since worshipping God is not merely to perform certain rites but also to be conscious of (the existence of) Him, this worshipping then reflects on the human style of life. Those rites contain within their meanings things which can be disclosed only by practising. In addition, various aspects of living one's life in such degrees ranking from the spiritual, intellectual, personal, family, social,

\footnotetext{
${ }^{11}$ This word is generally translated to mean "people or nation" but a clearer meaning, if to be applied to Islam, as described by Imtiyaz Yusuf (2006) is "worldwide community bound by a fraternal spirit of brotherhood which is related by faith and practice of Islam."
}

economic, political and international, must be fulfilled and getting along with each other through surrendering oneself to God and following His Guidance, which apparently teaches that people in their dealings with each other should be more benevolent and charitable.

The parable of those who spend their possessions for the sake of God is that of a grain out of which grow seven ears and in every ear a hundred grains: for God grants manifold increase unto whom $\mathrm{He}$ wills; and God is infinite, allknowing. They who spend their possessions for the sake of God and do not thereafter mar their spending by stressing their own benevolence and hurting [the feelings of the needy] shall have their reward with their Sustainer, and no fear need they have, and neither shall they grieve. A kind word and the veiling of another's want are better than a charitable deed followed by hurt; and God is self-sufficient, forbearing. O you who have attained to faith! Do not deprive your charitable deeds of all worth by stressing your own benevolence and hurting [the feelings of the needy], as does he who spends his wealth only to be seen and praised by men, and believes not in God and the Last Day: for his parable is that of a smooth rock with [a little] earth upon it - and then a rainstorm smites it and leaves it hard and bare. Such as these shall have no gain whatever from all their [good] works: for God does not guide people who refuse to acknowledge the truth. And the parable of those who spend their 
possessions out of a longing to please God, and out of their own inner certainty, is that of a garden on high, fertile ground: a rainstorm smites it, and thereupon it brings forth its fruit twofold; and if no rainstorm smites it, soft rain [falls upon it] . . . O you who have attained to faith! Spend on others out of the good things which you may have acquired, and out of that which We bring forth for you from the earth; and choose not for your spending the bad things which you yourselves would not accept without averting your eyes in disdain. And know that God is self-sufficient, ever to be praised. Satan threatens you with the prospect of poverty and bids you to be niggardly, whereas God promises you His forgiveness and bounty; and God is infinite, all-knowing, granting wisdom unto whom He wills: and whoever is granted wisdom has indeed been granted wealth abundant. But none bears this in mind save those who are endowed with insight. For, whatever you may spend on others, or whatever you may vow [to spend], verily, God knows it; and those who do wrong [by withholding charity] shall have none to succor them. If you do deeds of charity openly, it is well; but if you bestow it upon the needy in secret, it will be even better for you, and it will atone for some of your bad deeds. And God is aware of all that you do...Those who spend their possessions [for the sake of God] by night and by day, secretly and openly, shall have their reward with their Sustainer; and no fear need they have, and neither shall they grieve. . And God does not love anyone who is stubbornly ingrate and persists in sinful ways. Verily, those who have attained to faith and do good works, and are constant in prayer, and dispense charity - they shall have their reward with their Sustainer, and no fear need they have, and neither shall they grieve . . . If, however, [the debtor] is in straitened circumstances, [grant him] a delay until a time of ease; and it would be for your own good - if you but knew it - to remit [the debt entirely] by way of charity. And be conscious of the Day on which you shall be brought back unto God, whereupon every human being shall be repaid in full for what he has earned, and none shall be wronged.

(Quran 2: 261-281)

Above all these is His Grace in granting free will. For God's Grace is limitless and a human being is free to choose. Not only in the matter of good or bad for one's own sake but in the matter of whether or not to believe in Him and His messages also (Quran 2: 256, 10: 99, 11: 28, 18: 6-7, 26: 3, 50: 45, 88: 21-22).

... Do what you will: verily, $\mathrm{He}$ sees all that you do (Quran 41: 40) And [it is up to you, $\mathrm{O}$ sinners, to] worship whatever you please instead of Him! ... (Quran 39: 15)

And say: "The truth [has now come] from your Sustainer: let, then, him who wills, believe in it, and let him who wills, reject it." (Quran 18: 29) 
Say: "For this, no reward do I ask of you [- no reward] other than that he who so wills may unto his Sustainer find a way!" (Quran 25: 57)

This, verily, is a reminder: let him who wills, then set out on a way to his Sustainer! (Quran 73: 19)

A warning to mortal man - to every one of you, whether he chooses to come forward or to hang back! (Quran 74: 36-37)

Nay, verily, this is an admonition - and whoever wills may take it to heart. (Quran 74: 54-55)

VERILY, all this is an admonition: whoever, then, so wills, may unto his Sustainer find a way (Quran 76: 29)

... whoever wills, then, let him take the path that leads towards his Sustainer! (Quran 78: 39)

NAY, verily, these [messages] are but a reminder: and so, whoever is willing may remember Him. (Quran 80: 11-12)

This [message] is no less than a reminder to the Alimeen (the worlds) - to every one of you who wills to walk a straight way. (Quran 81: 27-28)

Since each dimension of worldly life has its own place within Islam's matrix, it thus can perform its own function, enable human beings to be at peace with oneself, community, and nature, and to gain happiness in both worlds. To be at peace with the earth or worldly life, however, one must also be at peace with his or her inner self, and this is impossible if one is not at peace with the Divine who has bestowed on humanity His Merciful Guidance.

\section{The concept of peace}

\section{Concept of peace as stated in the Quran}

The Quranic concept of peace has been laid down both as a means and end. A peaceful end can only be achieved through a peaceful means for that: "Goodness and evil can never be equal. Repel [evil] with good then verily he, between whom and you was hatred, become as if your friend and intimate" (Quran 41:34).

In order to attain peace, both as a means and an end, a Muslim should live his/her life realizing that this worldly life is only a journey (Quran 64: 3) testing one submission since one end is surely to return to God, Assalaam (the Whole Peace or the Source of Peace).

As the Quran calls Heaven Dar al-Salaam which is the abode of peace and perfection (10: 25, 6: 127), so the paths of righteousness and virtue that lead to God are also called subul al-salaam (5: 16). The greeting of peace both in this world and in the Hereafter is Assalam 'alaikum (peace be upon you) which is emphasized and taught as a proper greeting for believers (13: 23-24, 33: 44, 10: 10, 14: 23, 16: 32, 39: 73, 50: 34, 54: 26). A journey to peace in Islam thus begins with the attainment of peace with the Creator, acquiring the righteous path and the virtue to end up peacefully in the hand of God. That is "submission". 
The very basic word salaam, hence, does not only signify the absence of war, violence and aggression, but it also means total well-being and happiness. The state of salaam is the state where everything finds its fulness, glory and perfection in the guarding of "submission."

Salaam, moreover, does not mean "peace" in the sense of being inactive, motionless, quiet or becoming dead. It is an active and dynamic involvement in keeping and restoring the right order. Salaam is both an individual quest for the peace and harmony of oneself and the contentment concerns for the well-being of all people regardless of their race, color and gender.

Total well-being and happiness, thus, requires a peaceful means in all living levels: individual, communal and universal. In order to have peace and harmony in society and in the world at large, it is necessary that human beings be developed in such a way that fulfills this end.

Guiding humans to reach the state of total well-being and happiness, the Quran very often states that people who follow God's guidance will have no fear nor grief. Since the state of fear and grief is the state of terror, war and violence where people have no security and cannot live one's life in harmony and the peaceful way, not even with oneself, the Quran ensures human beings who have trust in God and righteously follow His Merciful Guidance their security and happiness, both in this world and the Hereafter.

Thereupon Adam received words [of guidance] from his Sustainer, and $\mathrm{He}$ accepted his repentance: for, verily, $\mathrm{He}$ alone is the Acceptor of Repentance, the
Dispenser of Grace. [For although] We did say, "Down with you all from this [state], there shall, none the less, most certainly come unto you guidance from Me: and those who follow My guidance need have no fear, and neither shall they grieve. (Quran 2: 37-38)

For, verily, those who have attained to faith [in this divine writ], as well as those who follow the Jewish faith, and the Sabians, and the Christians - all who believe in God and the Last Day and do righteous deeds - no fear need they have, and neither shall they grieve. (Quran 5: 69)

And We send [Our] messagebearers only as heralds of glad tidings and as warners: hence, all who believe and live righteously no fear need they have, and neither shall they grieve. (Quran 6: 48)

O children of Adam! Whenever there come unto you apostles of your own, conveying My messages unto you, then all who are conscious of $\mathrm{Me}$ and live righteously - no fear need they have and neither shall they grieve. (Quran 7: 35)

Oh, verily, they who are close to God-no fear need they have and neither shall they grieve: they who have attained to faith and have always been conscious of Him. (Quran 10: 62-63)

But God will safeguard all who are conscious of Him, [and will 
grant them happiness] by virtue of their [inner] triumphs; no evil shall ever touch them and neither shall they grieve. (Quran 39: 61)

It also teaches individuals to be just, honest, truthful, patient, contented, charitable, cheerful and tolerant and urges people to control their anger and to forgive others when they do wrong to them.

Be kind and God loves those who are kind. (Quran 2: 195)

The reward of an evil is an equal evil but if a person forgives and makes reconciliation, his reward is due from God. Surely God loves not the wrongdoers. (Quran 42: 40)

And pay heed unto God and the Apostle, so that you might be graced with mercy. And vie with one another to attain to your Sustainer's forgiveness and to a paradise as vast as the heavens and the earth, which has been readied for the God-conscious who spend [in His way] in time of plenty and in time of hardship, and hold in check their anger, and pardon their fellow-people because God loves the doers of good; and who, when they have committed a shameful deed or have [otherwise] sinned against themselves, remember God and pray that their sins be forgiven - for who but God can forgive sins? - and do not knowingly persist in doing whatever [wrong] they may have done. These it is who shall have as their reward forgiveness from their Sustainer . . (Quran 3: 132-136)
As to the communal level, the law of Islam emphasizes justice and fair dealings with all people. Since justice is a pivotal means of attaining peace, the believers have to be just and to maintain justice all the time, even with their own enemies. The Quran says:

. . And never let your hatred of people who would bar you from the Inviolable House of Worship lead you into the sin of aggression: but rather help one another in furthering virtue and God-consciousness, and do not help one another in furthering evil and enmity; and remain conscious of God: for, behold, God is severe in retribution! (5:2);

O you who believe, stand out firmly for God, as witnesses to fair dealing and let not the hatred of others to you make you swerve to wrong and depart from justice. Be just, that is next to piety. Be conscious of God, for God is wellacquainted with all that you do (5: 8 see also 4: 135 and 6: 152).

Behold, God enjoins justice and the doing of good and generosity towards [one's] fellow-men; and He forbids all that is shameful and all that runs counter to reason, as well as envy; [and] He exhorts you [repeatedly] so that you might bear [all this] in mind. (16:90)

Wherever justice is not done, it eventually turns into oppression. The opposite of justice in Islam is hence not injustice but oppression, which, God has pointed out, is even worse than killing (Quran 2: 191) and does not allow under any circumstances. 
Justice requires fairness, which, with regard to economics, means dealing without cheating, exploitation, fraud and deception as well as coercive policies. Islam also considers gambling and interest to be kinds of fraud and exploitation. The Quran teaches that these evil manners do not only create poverty and inequality in society but they also breed hatred, animosity and violence. Hence, while in law and the political dimensions as well as the economic realm, the Quran strongly commands justice and its moral and ethical teachings clearly emphasize benevolence, charity and kindness.

As peace is an active involvement, it comes when people take their actions seriously. Thus, the Quran teaches that human beings are responsible. Every person is responsible for what he or she does. Responsibility is first of all before God. Every person has direct access to God. There is no need for mediators or intercessors. Prophets only work as teachers and implementing models. No one should pass the blame on to someone else for as it says in the Quran: "No bearer of the burden shall be made to bear the burden of another [in the Hereafter]" (6: 164; 17: 15; 35: 18; 39: 7; 53:38).

\section{The Quran also says:}

Not according to your desires, nor those of the People of the Book, whosoever works evil, will be requited accordingly. He will not find beside God any protector or helper. If any do deeds of righteousness, be they male or female, and have faith, they will enter heaven and not the least of injustice will be done to them. (4: 123-124)
For social cohesion and harmony, the Quran teaches that we must recognize all human beings as one family.

$\mathrm{O}$ humankind! Be conscious of your Sustainer, who has created you out of one living entity, and out of it created its mate, and out of the two spread abroad a multitude of men and women. And remain conscious of God, in whose name you demand [your rights] from one another and of these ties of kinship. Verily, God is ever watchful over you! (Quran 4: 1)

The family is a strong unit both for the development of individuals and society. Islam urges believers to pay special attention to their families. Peace in the family comes when spouses respect, love, and have care for each other. In a family where sexual morality is observed, fornication, adultery and homosexuality is banned and a proper order of responsibility and authority in the family is maintained.

As for the treatment of tensions and conflicts that exist within members of societies as well as in their relations with other societies, Islam emphasizes the peaceful resolution of conflicts in every situation. The Quran teaches that reconciliation is the best (4: 35, 42: 40). Peace and reconciliation should be established in the family to reduce tension and break-ups. Whenever two parties are quarreling or fighting with each other, it is the duty of believers to make reconciliation among them.

And if a woman has reason to fear ill-treatment from her husband, or that he might turn away from her, 
it shall not be wrong for the two to set things peacefully to rights between themselves: for peace is best and selfishness is everpresent in human souls. But if you do good and are conscious of Him - behold, God is indeed aware of all that you do. (Quran 4: 128)

Hence, if two groups of believers fall to fighting, make peace between them; but then, if one of the two [groups] goes on acting wrongfully towards the other, fight against the one that acts wrongfully until it reverts to God's commandment; and if they revert, make peace between them with justice, and deal equitably [with them]: for verily, God loves those who act equitably! (Quran 49: 9)

Eventually, the very first verse of the Quran, the un-numbered verse of Basmalah, declares "In the name of God, the Most Merciful the Most Compassionate." This verse, which is repeated 114 times in the Quran, shows that the One God is the God of Mercy and Compassion and His book of Guidance is also the book of Mercy. People in the realm of Islam must also possess the quality of mercy and compassion. Otherwise, they cannot be true believers.

.. . Now there has come unto you from God a light and a clear divine writ, through which God shows unto all that seek His goodly acceptance of the paths leading to salvation and, by His grace, brings them out of the depths of darkness into the light and guides them on to a straight way. (Quran 5: 15-16)
And [know that] God invites [humans] unto the abode of peace, and guides whom that wills [to be guided] on to a straight way. (Quran 10: 25)

According to the message of Islam, both individual and collective happiness lies in disciplining human faculties so that people may produce a harmonious and peaceful individual and social life. If they remain undisciplined, they may drive people to immorality, illicit sexual relationships, unlawful livelihoods, tyranny, injustice, deception, falsehood and all other crimes and sinful ways. To prevent the ensuing chaos and suffering, one must submit to an authority that guides and regulates collective affairs. Since a person normally will not accept the authority of another, humanity needs a universal intellect to whose authority all may assent to freely. That guidance is, in Islam, the Path and Message that is revealed and perfected by God through His Messengers.

Peace in Islam is thus not required for the sake of peace. It is required for the sake of a greater purpose and that is salvation. It was due to the importance that no Islamic activity be carried out except in peaceful conditions that the Prophet always wanted to maintain peace, even at the price of unilateral adjustment.

\section{Concept of peace and war as implemented by the prophet}

It would be blindly naïve to say that the world we live in is free of conflict, violence and war.Without leaving any bit of human nature out of context, the Quran as God's Merciful Guidance on various occasions informs and exemplifies the differences and compares good and evil (bad), right and wrong, truth and falsehood 
and even peace and war for humanity who has been granted the will to freely choose. It is, however, firmly stated also that only good-doers will earn God's rewards, especially in the Hereafter.

As such, the mission of Prophet Muhammad, as well as of the other messengers who brought the universal message of Islam, does not end with the announcement of the message. He has to explain to the listeners the implications of the Islamic creed, the moral code, the divine injunctions and commandments and the form of worship that sustains the whole system. He has to exemplify the faith so others can pattern their participation on the evolution of Islamic culture and civilization. The believers must grow under his guidance into an organized community so that God's Word will prevail over all other words.

During the first thirteen years of his prophetic mission, the Prophet and his followers were subjected to the most brutal persecution by the Quraish Makkans. They were even forced to live in a valley adjacent to Makkah and subjected to a very severe form of boycott for two or three years. Subsequently, they were driven out of their homes and all their property confiscated and many of them were tortured and killed; and they would all have been massacred if they had not migrated to Madinah.

In Madinah, the people of the city received the Muslims very honorably, and eventually the Prophet Muhammad was accepted as the leader of the community. Hearing of the popularity of the Prophet in Madinah, the Makkans were upset for they expected a campaign from Madinah to take revenge on them. Fearing this, they wanted to destroy Muhammad and "his" Islam.

The fear, which was intensified by some events, prompted the Makkans to gather a powerful army and march towards Madinah. At this time, the Prophet and his followers could have migrated to some other cities to escape the Makkan army; for the Muslims had only one-third of the large army that was marching towards them. In addition, they were ill-equipped for war. Nevertheless, at this time, God's command came to the Prophet to stand his ground and fight. It was in this context that permission to fight was given.

This battle took place at Badr, where the Muslims, who were only 313 in number, and had very little war equipment - by the standards of those days - defeated a wellequipped army of a thousand fighters from Makkah. After this battle, the Makkans did not remain idle; their pride wounded, they waged many more battles with the Muslims.

Meanwhile, the Muslims were growing in number and strength in Madinah. Under divine guidance, the Prophet was able to form a society and a government in Madinah. Its constitution was the Quran; its laws derived from the Quran. It was a truly Islamic government, which had to make provisions for those who had not become Muslims. Those who did not become Muslims were not compelled to become Muslims but naturally, they were asked to obey the laws of the government.

The life of the Prophet Muhammad during his twenty-three prophetic years can then be divided into two main periods: Makkan and Madinan. The Quran revealed during the thirteen years of the Makkan period concentrates mainly on the fundamentals 
such as the assertion of the Unity and Sovereignty of God, the Day of Judgement and the Resurrection, the reckoning and the reward, stories of the prophets, moral corruption, yet reflects also how the Prophet dealt with persecution, oppression, tyranny and other forms of aggression.

The Makkan period was inscribed in the memory of Muslims as a period of unbearable persecution and torture when not only the poor and unprotected but also those who were from the elite and powerful members of the Quraish were severely persecuted and when Muslims were forbidden to fight back. In the initial stage, the Prophet was given the command to perform the preaching of invitation by observing patience.

Arise and warn! And thy Sustainer's greatness glorify! And thine inner self purify! And all defilement shun! And do not through giving seek thyself to gain but unto thy Sustainer turn in patience. (Quran 74: 2-7)

Thus, when the Makkan pagans had begun their cruel persecution of the Muslims, some of the faithful, reacting to this grievous injustice, asked the Prophet's permission to do battle with their persecutors. The Prophet, however, went on exhorting them to exercise patience and is reported to have said, "I have been commanded only to perform dawa'ah (preaching, invitation), communication of the message of God. I have not been given permission to do battle." In the light of such inhuman persecutions, the Prophet deemed it wise to advise his followers to conceal their conversion, in both word and deed. He took the decision to meet them secretly lest Quraish should get to know of his plans and so take measures that might foil his goals. He also had in mind to avoid any sort of open confrontation because such a thing at this early stage would not do any good or be in the interest of the preaching missions which were still vulnerable and not fully fledged. Meanwhile, in order to save his followers from maltreatment, the Prophet permitted the poor and unprotected to emigrate to Abyssinia (Ethiopia) but chose to keep back the powerful ones such as Abu Bakr, 'Umar and $\mathrm{Sa}^{\prime} \mathrm{d}$ ibn Abi Waqqas in Makkah. Later on, as circumstances warranted, the command to migrate to Madinah was revealed.

Now as for those who forsake the domain of evil in the cause of God, after having suffered wrong [on account of their faith], We shall most certainly grant them a station of good fortune in this world but their reward in the life to come will be far greater yet, if they [who deny the truth] can but understand. For those who having attained to patience in adversity, in their Sustainer place their trust!

(Quran 16: 41-42)

The basic reason lying behind the peaceful struggles in the Makkan period, besides being that they were the minority, was that only strong believers could survive the "test" that was given through the severe harassment and hostility of the Quraish Makkan. The Makkan period thus is considered a prepared-foundation, especially in spirituality, for the Islamic movement to come, which, when circumstances further changed, the command to do defensive battle was then revealed. 
While the ten years of Madinan period touches briefly upon those of the Makkan topics, themes that are not found in the Makkan revelations are those relating to maintaining community order such as the social and legal implications concerning marriage, divorce, inheritance, punishment and so on, including the permission to engage in defensive armed struggles.

Since the permission to fight back against the enemy was given to the Prophet for the first time in Madinah when a series of the Makkan-waged battles took place, a number of the Madinan verses teach Muslims the principles of war and how to deal with prisoners of war while forbidding retreat during an attack except as a trick to trap the enemy. They also encourage Muslims to prepare themselves with the best weapons and battle gear they can find.

Permission [to fight] is given to those against whom war is being wrongfully waged and, verily, God has indeed the power to succor them - those who have been driven from their homelands against all right for no other reason than their saying, "Our Sustainer is God!" For, if God had not enabled people to defend themselves against one another, [all] monasteries and churches and synagogues and mosques - in [all of] which God's name is abundantly extolled would surely have been destroyed [ere now]. And God will most certainly succor him who succours His cause: for, verily, God is most Powerful, Almighty.

(Quran 22: 39-40)
In conjunction with the above verses of 22: $39-40$ and of 2: $190-193$, it is worth mentioning the following verse, which in addition, expresses a general truth applicable to many situations:

Fighting is ordained for you, even though it be hateful to you; but it may well be that you hate a thing while it is good for you, and it may well be that you love a thing while it is bad for you: and God knows, whereas you do not know.

(Quran 2: 216)

Even though it is hateful, fighting, especially fighting against oppression or aggression, is ordained for the sake of justice and to bring peace and it is therefore considered as in the name (cause) of God (Quran 2: 244). In the light and essence of the "Islamic" realm, there is no war that is "holy" under any circumstances whatsoever. God, the only "Holy," does not encourage war but rather encourages peace whenever possible.

Now when you meet [in war] those who are bent on denying the truth, smite their necks until you overcome them fully, and then tighten their bonds ${ }^{12}$; but thereafter [set them free,] either by an act of grace or against ransom, so that the burden of war may be lifted: thus [shall it be]. And [know that] had God so willed, $\mathrm{He}$ could indeed punish them [Himself]; but [He wills you to struggle] so as to test you [all] by

\footnotetext{
${ }^{12}$ This expression, according to almost all the commentators, denotes the taking of prisoners of war. Moreover, it may also refer to any sanctions or safeguards that would be unlikely to make the aggression be resumed in the foreseeable future (Asad 1980: 778).
} 
means of one another. And as for those who are slain in God's cause, never will $\mathrm{He}$ let their deeds go to waste: (Quran 47: 4)

For "those who are bent on denying the truth" in the above verse and try to deprive the Muslims of their social and political liberty and thus make it impossible for them to live in accordance with the principles of their faith, a just war then becomes allowable and, even more, a duty. The whole of the above verse thus relates to war actually in progress and it was revealed after the earliest Quranic reference to physical warfare, 22: 39-40 (Asad 1980).

Furthermore, God has not asked Muslims to fight non-believers for the reason that they are non-believers. As stated in the Quran, religious diversity is tolerated because God's command is for human beings to be united in obeying Him, in all paths of life. It was because they were the persecutors or aggressors that fighting against them became necessary. It is clearly stated, however, that permission to fight is given only until they cease hostilities and war is permitted only in self-defence.

It is not for thee [O Prophet] to make people follow the right path, since it is God [alone] who guides whom He wills ... (Quran 2: 272)

Say: "The truth is from your Lord": Let him who will believe, and let him who will, reject [it]. . . (Quran 18: 29)

No force is to be used in the matter of religious belief: "Let there be no compulsion in religion: truth stands out clear from error..." (Quran 2: 256)

Hence, make ready against them whatever force and war mounts you are able to muster, so that you may deter thereby the enemies of God, who are your enemies as well, and others besides them of whom you may be unaware, [but] of whom God is aware. And whatever you may expend in God's cause shall be repaid to you in full, and you shall not be wronged. But if they incline to peace, incline thou to it as well, and place thy trust in God: verily, $\mathrm{He}$ alone is All-Hearing, AllKnowing! (Quran 8: 60-61)

And fight in God's cause against those who wage war against you but do not commit aggression for, verily, God does not love aggressors. And slay them wherever you may come upon them, and drive them away from wherever they drove you away for oppression is even worse than killing. And fight not against them near the Inviolable House of Worship unless they fight against you there first; but if they fight against you, slay them: such shall be the recompense of those who deny the truth. But if they desistbehold, God is much-forgiving, a dispenser of grace. Hence, fight against them until there is no more oppression and all worship is devoted to God alone; but if they desist, then all hostility shall cease, save against those who [wilfully] do wrong. Fight during the sacred months if you are attacked: for a violation of sanctity 
is [subject to the law of] just retribution. Thus, if anyone commits aggression against you, attack him just as he has attacked you - but remain conscious of God, and know that God is with those who are conscious of Him. (Quran 2: 190-194)

In accordance with God's commands, the Prophet instructed the Muslim commanders in chief not to join anything in worship along with God; not to steal; not to commit illegal sexual intercourse; not to kill children; not to accuse an innocent person (to spread such an accusation among people) or to invent utterance or slander; not to be disobedient (when ordered) to do good deeds (AlBukhari 2: 17, 58: 232). Also, "Fight in the cause of God. Fight the combatants who deny God. Do not be embittered. Do not be treacherous. Do not mutilate. Do not kill children or those in convents." $\mathrm{He}$ commanded that the life of civilians, foliage, livestock, clergy and places of worship are to be protected. The companions were instructed to treat prisoners with more than just decency: "It is my recommendation that you be good to the captives," and that: "I entrust the captives to your charity" (Hathout 2002: 19-27).

Islam then decrees protection for the captives and the wounded as God has praised the believers for these manners in the Quran (76: 7-10) this means:

[The truly virtuous are] they [who] fulfill their vows and stand in awe of a Day the woe of which is bound to spread far and wide, and who give food - however great be their own want of it - unto the needy and the orphaned and the captive, [saying, in their hearts,] "We feed you for the sake of God alone: we desire no recompense from you, nor thanks: behold, we stand in awe of our Sustainer's judgement on a distressful, fateful Day!"

Thus, there are only two grounds for waging war or for appeal to arms that might fit Islamic teachings: in the first place, in self-defence, and, in the second place, for establishing conditions of universal peace or to enforce the regime of law or order in human society. However, even though war or appealing to arms is tolerated in such conditions like being tyrannized over and driven out of homes, if there is a possibility to avoid war, then this opportunity, as long as it is for the just cause, must be seized.

Nevertheless, even in times of war Muslims must respect their adversary's humanity. Brutal and barbaric atrocities are prohibited. Islam condemns the barbaric killing of any human being. During military actions, civilians must not be targeted, as long as they do not attack, provoke or share directly in the war. Enemies, even at time of war, must be treated justly. Prisoners of war have basic human rights, as stated in Shari $a{ }^{13}{ }^{13}$ If

\footnotetext{
${ }^{13}$ Shariah is primarily meant for all Muslims but applies to a certain extent also for people living inside a Muslim society. The word shariah as used in the Quran (45: 18) means "a clear religious path, a course in the affair, a plain way of commandment". In practice, it denotes a prescribed law derived from the Quran and the Traditions of the Prophet in conjunction with older Arabic law systems, parallel traditions and the work of Muslim jurists over the first two centuries of Islam. Some countries formally institute it as the law of the land, enforced by the courts. Thus, the
} 
victory is achieved in any war for justice, then there is to be no oppression, revenge or injustice to the people of the enemy. Nor must there be control over the sources of the wealth of the nation or people, or even the establishment of colonial regimes. Justice and freedom must be established while tolerance towards cultures and peoples is also required.

With regard to the Traditions of the Prophet in general, there was once a man who came to the Prophet and asked (thrice), "O Prophet, give me advice which will enable me to manage all the affairs of my life." The Prophet told him thrice: "Don't be angry and furious" (Al-Bukhari, Hadeeth 73: 137). Anger is already a negative mood that should be well controlled and not be fueled more with the fire of fury. One needs to restrain anger and be patient to promote a better relationship among people. The Prophet had at many times advised people never to take a negative course of actions, and to keep to peaceful and positive behavior in all situations, even in the face of provocation:

Anger comes from the devil; the devil was created of fire and fire is extinguished only with water; so when one of you becomes angry, he should perform ablutions. (Abu Dawud, Hadeeth 4766)

When one of you becomes angry while standing, he should sit down. If the anger leaves him,

way shariah is applied from country to country can vary widely and mostly embodied with "opinions" and local traditions and culture. Hence, a more correct designation for the wide use of "applied" shariah today would be the law system of designated Muslims rather than the "Islamic Law." well and good; otherwise he should lie down. (Abu Dawud, Hadeeth 4764)

I know a word, the saying of which will cause him to relax, if he does say it: "I seek Refuge with God from Satan" then all his anger will go away. (Al-Bukhari, Hadeeth 54: 502)

I know a phrase, which, if he repeats it, could get rid of this angry feeling-He should say: "I seek refuge with God from the accursed devil." (Abu Dawud, Hadeeth 4762)

The strong is not the one who overcomes the people by his strength, but the strong is the one who controls himself while in anger. (Al-Bukhari, Hadeeth 73: 135)

Therefore, one of the keys to control oneself during anger is to seek refuge with God from Satan that keeps waswas (whispering) to influence human perception to follow its way in promoting evil and creating disputes:

And tell My servants that they should speak in the most kindly manner [unto those who do not share their beliefs]: verily, Satan is always ready to stir up discord between men - for, verily, Satan is the human's open foe!

(Quran 17: 53)

On another occasion, the Prophet said, "If one of you becomes angry then he should be silent." This is important advice because during anger, most of our actions and speech may not be well controlled and 